\title{
PENGARUH POLA PADA SISTEM CAM MENGGUNAKAN METODE ELEMEN HINGGA
}

\author{
Nur Muhammad Ariseno ${ }^{1}$, Afri Medika Utama ${ }^{1}$, Bambang Setiawan ${ }^{1}$, dan Noegroho Djarwanti ${ }^{1}$

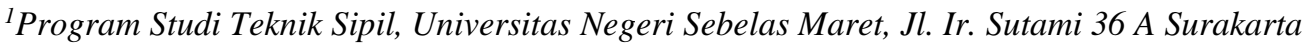 \\ Email: mariseno24@gmail.com
}

\begin{abstract}
Cakar Ayam Modification System (CAM) has been widely used as one of the solutions to road pavement problems in soft subgrade, although construction costs were initially high, the total costs incurred were smaller due to small maintenance costs. This research analyzes the deflection produced in a triangle patterned CAM system and quadrilateral with variations in the distance between claws of $2.25 \mathrm{~m}$. Loading uses truck loads based on SNI 17252016 with three different position variations each in the middle and edge of the pavement. The analysis was carried out using Finite Element Method-based software which has been proven to be able to approach the original conditions in the field. The results of the analysis show that the CAM pattern with triangular pattern is better at reducing deflection that occurs compared to quadrilateral CAM systems. The deflection difference produced by the triangular CAM system against the clawless pavement system reached $36.97 \%$ while on the quadrilateral CAM system the difference was only $28.56 \%$.
\end{abstract}

Keywords: pavement, CAM, FEM, deflection.

ABSTRAK
Sistem Cakar Ayam Modifikasi (CAM) telah banyak digunakan sebagai salah satu solusi dalam permasalah perkerasan jalan pada tanah dasar lunak, walaupun biaya konstruksi awalnya tinggi, total biaya yang dikeluarkan lebih kecil karena biaya perawatan yang kecil. Penelitian ini menganalisis lendutan yang dihasilkan pada sistem CAM berpola segitiga dan segiempat dan memiliki variasi jarak antar cakar 2,25 m. Pembebanan menggunakan beban truk berdasarkan SNI 17252016 dengan tiga variasi posisi yang berbeda masing-masing berada pada tengah dan tepi perkerasan. Analisis dilakukan menggunakan software berbasis Metode Elemen yang sudah terbukti dapat mendekati kondisi asli di lapangan. Hasil analisis menunjukkan bahwa sistem CAM berpola segitiga lebih baik dalam mereduksi lendutan yang terjadi dibandingkan dengan sistem CAM berpola segiempat. Selisih lendutan yang dihasilkan oleh sistem CAM berpola segitiga terhadap sistem perkerasan tanpa cakar mencapai 36,97\% sedangkan pada sistem CAM berpola segiempat selisihnya hanya $28,56 \%$.

Kata kunci: perkerasan jalan, CAM, MEH, lendutan.

\section{PENDahuluan}

Banyak perkerasan jalan yang harus dibangun di atas tanah lunak yang dapat menimbulkan masalah dikemudian hari. Tanah lunak memiliki daya dukung yang relatif rendah sehingga apabila diberi beban contohnya perkerasan jalan, maka perkerasan tersebut akan mengalami penurunan. Penurunan tersebut dapat mengakibatkan kerusakan pada perkerasan jalan karena penurunan yang terjadi tidak seragam, sehingga perkerasan tersebut mengalami keretakan, bergelombang, berlubang, dan lain sebagainya. Salah satu solusi yang dapat mengatasi permasalah tersebut adalah menggunakan fondasi sistem cakar ayam (CA). Sistem ini pertama kali ditemukan oleh Sediyatmo pada tahun 1961 yang pada awalnya diperuntukkan sebagai fondasi menara listrik tengangan tinggi yang berada di daerah Ancol dan memiliki tanah dasar berupa rawa-rawa. Sistem cakar ayam memiliki cakar yang terbuat dari bahan beton dan memiliki berat hingga 1 ton. Sistem cakar ayam kemudian dikembangkan oleh Suhendro dkk menjadi sistem Cakar Ayam Modifikasi (CAM), pengembangan meliputi perubahan bahan cakar yang awalnya terbuat dari beton diubah menjadi berbahan baja ringan galvanis yang memiliki berat hanya $35 \mathrm{~kg}$.

Evaluasi terkait sistem CAM telah banyak dilakukan oleh peneliti diantaranya penelitian yang dilakukan oleh Daud (2008) menghasilkan kesimpulan bahwa sistem CAM memiliki kinerja yang lebih baik dibandingkan dengan sistem perkerasan beton konvensional, Firdiansyah (2009) dalam penelitiannya menyimpulkan bahwa lendutan terbesar dihasilkan oleh beban yang diletakkan ditepi perkerasan, dan Setiawan (2015) yang menghasilkan kesimpulan bahwa kemampuan dukung sistem CAM dipengaruhi oleh jumlah cakar, friction pada selimut cakar, dan ada koperan. Penelitian-penelitian tersebut belum mengevaluasi pengaruh dari pola cakar pada sistem CAM, oleh karena itu perlu dilakukkan penelitian yang mengkajinya. 
Penelitian ini bertujuan untuk mengetahui hasil lendutan pada sistem CAM berpola segitiga dan segiempat akibat beban truk dengan jarak antar cakar 2,25-meter yang selanjutnya akan dibandingkan dengan hasil lendutan pada perkerasan tanpa cakar. Penelitian ini menggunakan data sekunder tanah berupa nilai koefisien reaksi vertikal tanah $\left(k_{v}\right)$, koefisien reaksi horisontal tanah $\left(k_{h}\right)$, dan koefisien geser tanah $\left(k_{\tau}\right)$ dari penelitian sebelumnya yang dilakukan Setiawan (2015) dan tanah tersebut diambil dari Kabupaten Ngawi. Geometri sistem CAM menggunakan uji model skala penuh jalan Indramayu-Pamanukan dengan variasi jarak antar cakar dan dimensi perkerasan jalan dimodelkan seluas $27 \mathrm{~m} \times 7,25 \mathrm{~m}$. Analisis pada penelitian ini menggunakan metode elemen hingga (MEH) yang juga pernah digunakan pada penelitian sebelumnya yang dilakukan Firdiansyah (2009).

\section{DASAR TEORI}

\section{Sistem CAM}

Sistem CAM mengandalkan tekanan lateral di sekitar cakar yang dipengaruhi oleh modulus reaksi subgrade untuk menahan pelat. Mardiyanto (2010) menyimpulkan nilai lendutan, momen, dan gaya lintang pelat yang terjadi semakin kecil ketika nilai reaksi subgrade membesar. Hardiyatmo (2014) menyatakan bahwa cakar pada sistem CAM bekerja seperti paku sehingga kontak antara perkerasan dengan tanah selalu terjaga.

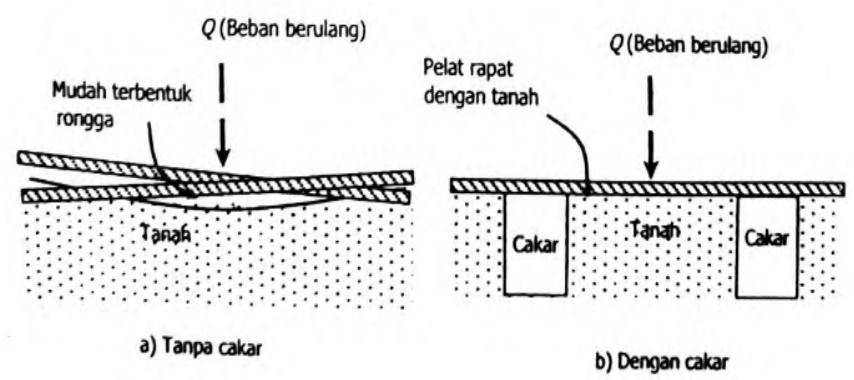

Gambar 1. Perbandingan sistem perkerasan tanpa cakar dan dengan cakar (Hardiyatmo, 2000)

\section{Metode Elemen Hingga}

Metode elemen hingga merupakan prosedur numeris yang digunakan secara luas untuk menyelesaikan persamaan diferensial dari permasalahan fisika yang berbasis komputer. Metode ini membagi-bagi permasalahan kompleks ke elemen-elemen kecil yang dapat diselesaikan dengan hubungan sesamanya. Elemenelemen yang dianalisis pada penelitian antara lain shell, spring, dan solid. Dalam penelitian ini menggunakan program SAP 2000 v.20. Menurut Cook (1989) dalam Rosyada (2017), elemen shell berupa permukaan lengkung dalam ruang yang mampu menahan beban luar dengan menggunakan elemen spring untuk menggambarkan nilai subgrade tanah.

\section{METODE PENELITIAN}

Data sekunder yang digunakan meliputi modulus reaksi subgrade, yaitu modulus subgrade vertikal tanah $\left(k_{v}\right)$ 13.196,14 kN/m3, modulus subgrade horizontal tanah $\left(k_{h}\right) 131.961,4 \mathrm{kN} / \mathrm{m} 3$, modulus subgrade horisontal tanah $\left(k_{\tau}\right) 5.078,74 \mathrm{kN} / \mathrm{m} 3$ yang berasal dari penelitian Setiawan (2015) dan material property berupa beton mutu K-350 dan baja mutu BJ 37. Sistem perkerasan memiliki ukuran $27 \mathrm{~m}$ x 7,25 m dengan jarak antar cakar 2,25 meter pada pola segitiga maupun pola segiempat. Sistem perkerasan yang digunakan sebagai pembanding terhadap sistem CAM adalah perkerasan tanpa cakar dengan koperan. Potongan melintang dari sistem CAM dan sistem perkerasan tanpa cakar dengan koperan dapat dilihat pada Gambar 2.

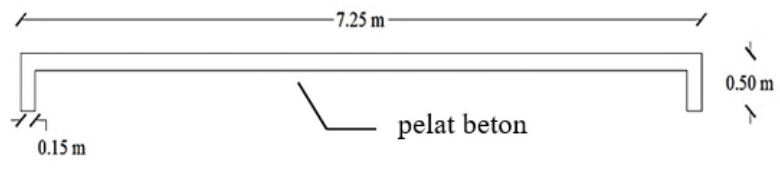

(a)
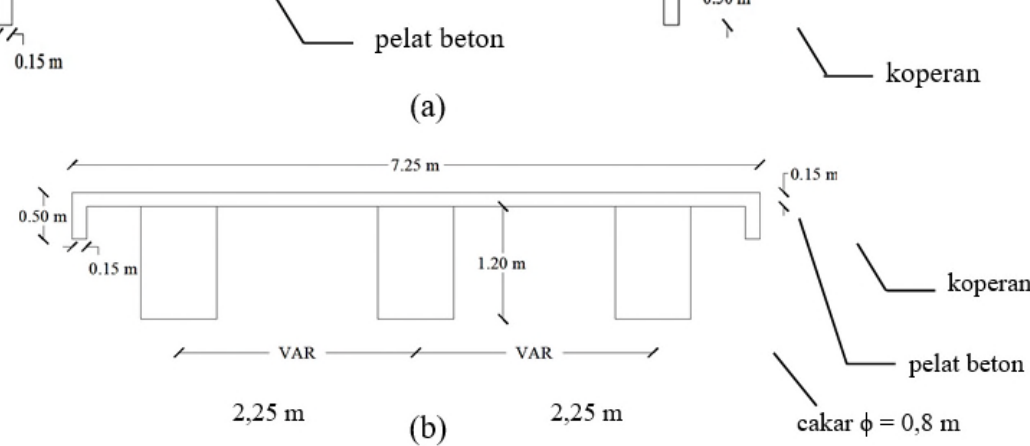

Gambar 2. (a) Sistem CAM dan (b) Sistem perkerasan tanpa cakar 
Beban yang digunakan pada penelitian ini adalah beban kendaraan truk yang mengacu pada SNI 17252016. Penelitian ini menggunakan beban truk yang memiliki sumbu pendek yaitu 5 meter pada setiap sumbu roda. Bidang kontak pada SNI yang semulanya berbentuk persegi panjang dikonversi menjadi lingkaran dengan luasan yang sama, yaitu $0,0375 \mathrm{~m}^{2}$ pada roda depan dan $0,1875 \mathrm{~m}^{2}$ pada roda tengah dan roda belakang.
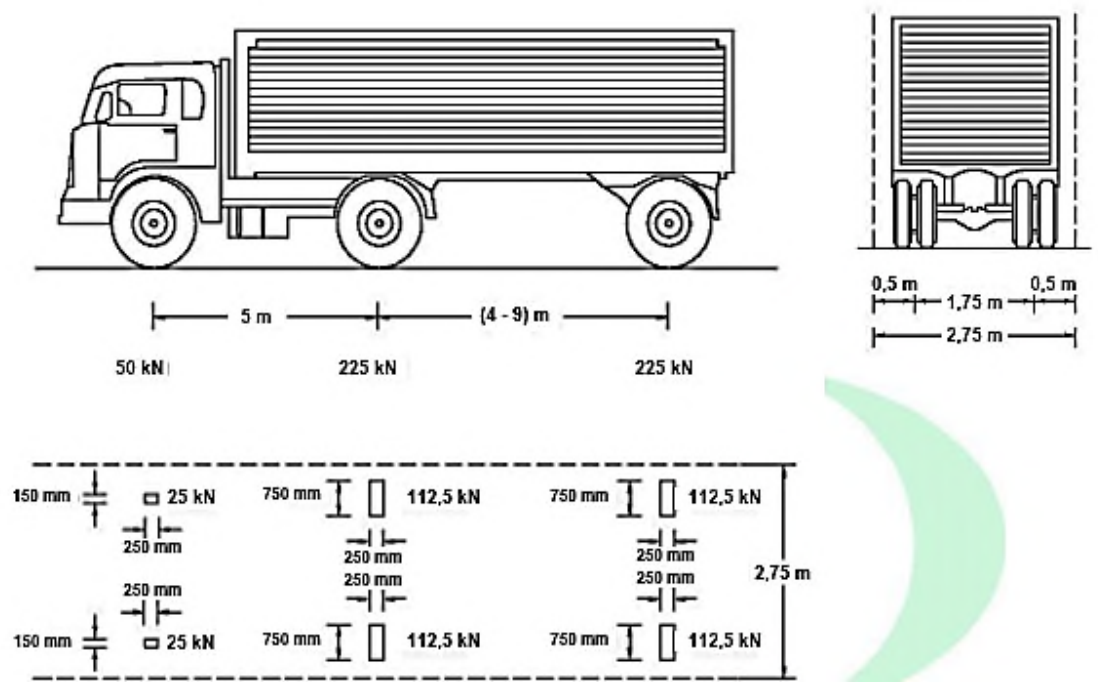

Gambar 3. Besarnya pembebanan truk (SNI 17252016 Pembebanan Jembatan)

Penempatan beban truk memiliki tiga variasi posisi pada masing-masing pola cakar, yang dinamakan sebagai tengah 1, tengah 2, dan tengah 3. Penempatan beban ini ditujukan agar dapat mewakili semua sisi pada perkerasan bagian tengah. Analisis lendutan pada penelitian ini meninjau lendutan pada perkerasan secara memanjang sehingga dapat terlihat dengan jelas pengaruh dari variasi pola pada sistem CAM. Gambar 4 menunjukkan denah penempatan beban truk pada sistem CAM dan pada perkerasan tanpa cakar memiliki posisi penempatan beban yang sama dengan sistem CAM.

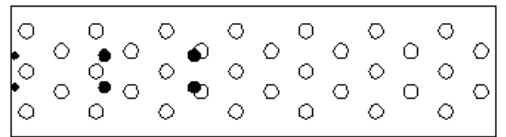

Tengah 1

$$
\begin{array}{lllllllllllll}
0 & 0 & 0 & 0 & 0 & 0 & 0 & 0 \\
0 & 0 & 0 & 0 & 0 & 0 & 0 & 0 & 0 & 0 & 0 & 0 & 0 \\
0 & 0 & 0 & 0 & 0 & 0 & 0 & 0
\end{array}
$$

Tengah 2

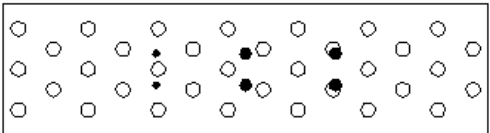

Tengah 3

Sistem CAM Pola $\triangle$
000000000000

- 080800000000

000000000000

Tengah 1

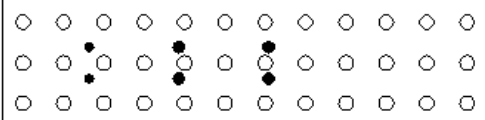

Tengah 2

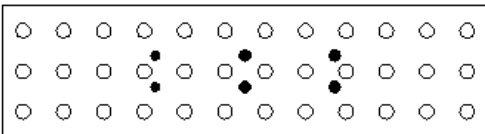

Tengah 3

Sistem CAM Pola

Gambar 4. Denah pembebanan sistem CAM pola segitiga dan segiempat 
Pemodelan sistem CAM dan perkerasan menggunakan beberapa elemen, yaitu elemen shell untuk memodelkan pelat, cakar, dan koperan, elemen solid 3D untuk memodelkan tanah di dalam cakar, dan elemen spring untuk memodelkan modulus reaksi subgrade $\left(k_{v}, k_{h}\right.$, dan $\left.k_{\tau}\right)$.

\section{HASIL DAN PEMBAHASAN}

Gambar 5 hingga Gambar 7 menunjukkan kurva lendutan pada sistem perkerasan tanpa cakar dan sistem CAM sedangkan Tabel 1 hingga Tabel 3 menunjukkan rekapitulasi lendutan akibat dari roda depan, tengah, dan belakang. Tinjauan dilakukan pada garis center line atau tepat di tengah perkerasan. Kurva-kurva ini menunjukkan bahwa sistem perkerasan tanpa cakar menghasilkan lendutan yang lebih besar dibandingkan dengan sistem CAM.

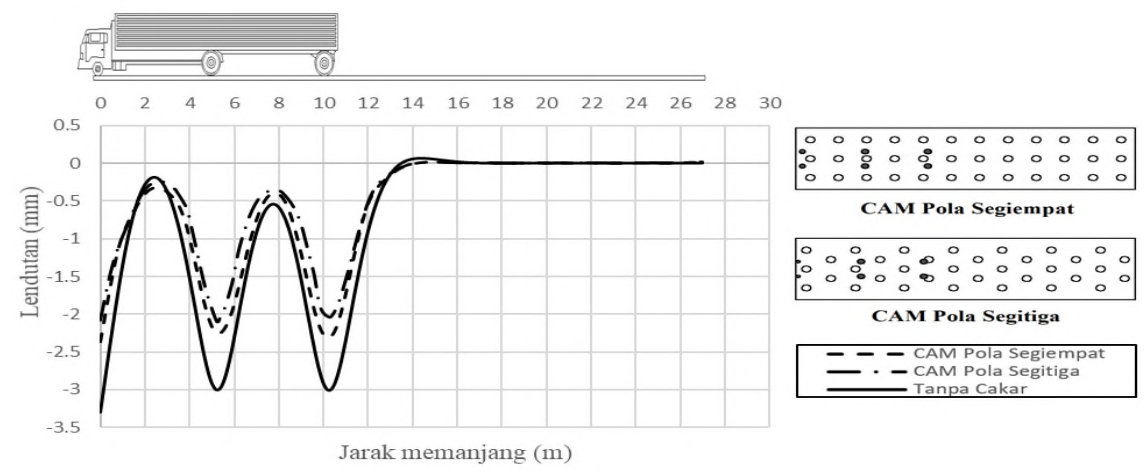

Gambar 5. Potongan arah memanjang akibat pembebanan Tengah 1

Tabel 1. Lendutan akibat pembebanan Tengah 1

\begin{tabular}{lccccc}
\hline \multirow{2}{*}{ Roda } & \multicolumn{5}{c}{ Tipe Perkerasan } \\
\cline { 2 - 6 } & $\begin{array}{c}\text { Tanpa Cakar } \\
(\mathbf{m m})\end{array}$ & $\begin{array}{c}\text { CAM Pola } \\
\text { Segiempat }(\mathbf{m m})\end{array}$ & Selisih (\%) & $\begin{array}{c}\text { CAM Pola } \\
\text { Segitiga (mm) }\end{array}$ & Selisih (\%) \\
\hline Depan & 3.300 & 2.364 & 28.364 & 2.090 & 36.67 \\
Tengah & 3.006 & 2.252 & 25.083 & 2.080 & 36.97 \\
Belakang & 3.011 & 2.310 & 23.281 & 2.041 & 32.22 \\
\hline
\end{tabular}

Gambar 5 menunjukkan bahwa lendutan mencapai puncaknya pada pusat beban (roda) berada, lendutan terbesar terjadi pada roda depan walaupun bebannya lebih kecil dibandingkan dengan roda tengah dan belakang. Hal ini dikarenakan pada daerah ujung perkerasan jumlah cakar yang menopang beban lebih sedikit dibandingkan dengan daerah tengah perkerasan dan kekakuan struktur pada daerah tepi lebih kecil dibandingkan dengan daerah tengah. Lendutan terbesar yang dihasilkan oleh sistem CAM berpola segiempatdan sistem CAM berpola segitiga berturut-turut adalah 2,364 $\mathrm{mm}$ dan 2,090 $\mathrm{mm}$ dengan selisih terhadap sistem perkerasan tanpa cakar sebesar $28,364 \%$ dan $36,67 \%$.

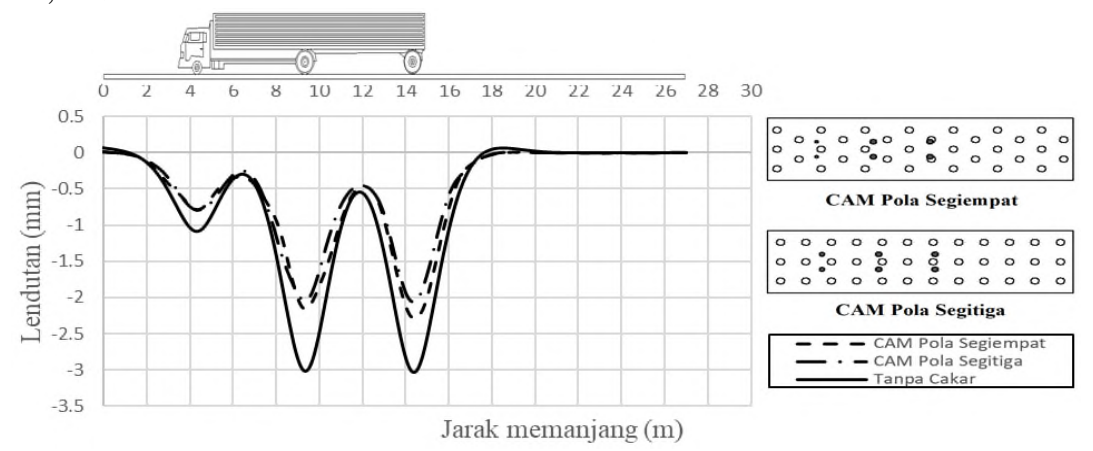

Gambar 6. Potongan arah memanjang akibat pembebanan Tengah 2

Tabel 2. Lendutan akibat pembebanan Tengah 2

\begin{tabular}{cccccc}
\hline \multirow{2}{*}{ Roda } & \multicolumn{5}{c}{ Tipe Perkerasan } \\
\cline { 2 - 6 } & $\begin{array}{c}\text { Tanpa Cakar } \\
(\mathbf{m m})\end{array}$ & $\begin{array}{c}\text { CAM Pola } \\
\text { Segiempat }(\mathbf{m m})\end{array}$ & Selisih $(\boldsymbol{\%})$ & $\begin{array}{c}\text { CAM Pola } \\
\text { Segitiga }(\mathbf{m m})\end{array}$ & Selisih (\%) \\
\hline Depan & 1.085 & 0.791 & 27.10 & 0.788 & 27.37 \\
Tengah & 3.011 & 2.166 & 28.06 & 2.043 & 32.15 \\
Belakang & 3.025 & 2.298 & 24.03 & 2.059 & 31.93 \\
\hline
\end{tabular}


Gambar 6 menunjukkan hal yang berbeda dengan Gambar 5, hal ini terlihat pada lendutan akibat roda depan yang jauh lebih kecil dibandingkan dengan lendutan yang dihasilkan pembebanan Tengah 1, ini terjadi karena pada daerah tengah kekakuan dan jumlah cakar yang menahan beban lebih besar dibandingkan dengan daerah ujung perkerasan. Lendutan yang terjadi di daerah tengah bentang perkerasan dipengaruhi oleh besar-kecilnya beban yaitu semakin besar beban semakin besar lendutan yang dihasilkan. Hal ini terlihat pada sistem CAM berpola segiempat maupun sistem CAM berpola segitiga lendutan terjadi pada roda belakang yaitu sebesar 2,298 $\mathrm{mm}$ dan 2,059 mm dengan selisih terhadap sistem perkerasn tanpa cakar sebesar 24,03\% dan 31,93\%.

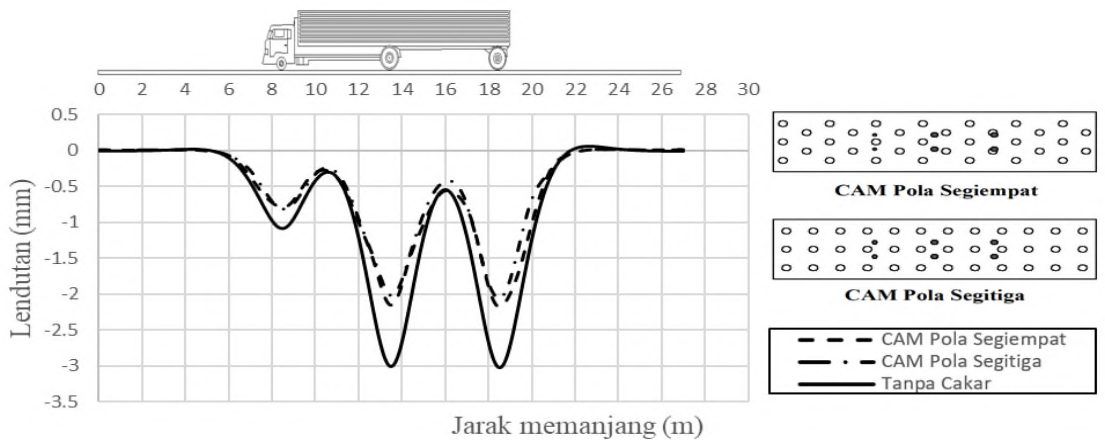

Gambar 7. Potongan arah memanjang akibat pembebanan Tengah 3

Tabel 3. Lendutan akibat pembebanan Tengah 2

\begin{tabular}{cccccc}
\hline \multirow{2}{*}{ Roda } & \multicolumn{5}{c}{ Tipe Perkerasan } \\
\cline { 2 - 6 } & $\begin{array}{c}\text { Tanpa Cakar } \\
(\mathbf{m m})\end{array}$ & $\begin{array}{c}\text { CAM Pola } \\
\text { Segiempat }(\mathbf{m m})\end{array}$ & Selisih $(\boldsymbol{\%})$ & $\begin{array}{c}\text { CAM Pola } \\
\text { Segitiga }(\mathbf{m m})\end{array}$ & Selisih (\%) \\
\hline Depan & 1.084 & 0.797 & 26.48 & 0.817 & 24.63 \\
Tengah & 3.011 & 2.151 & 28.56 & 2.016 & 33.05 \\
Belakang & 3.027 & 2.177 & 27.70 & 2.06 & 31.58 \\
\hline
\end{tabular}

Gambar 7 menunjukkan hal yang sama dengan Gambar 6 yaitu lendutan yang dihasilkan oleh roda tengah dan roda belakang lebih besar dibandingkan dengan roda depan. Hal ini menunjukkan daerah yang paling kritis adalah daerah ujung perkerasan sedangkan daerah tengah bentang cendrung memiliki pengaruh yang sama terhadap lendutan yang ditunjukkan oleh selisih sistem CAM yang sama terhadap sistem perkerasan tanpa cakar. Lendutan terbesar yang dihasilkan oleh sistem CAM berpola segiempat dan segitiga terjadi pada roda belakang yaitu sebesar 2,177 $\mathrm{mm}$ dan 2,06 $\mathrm{mm}$ dengan selisih terhadap sistem perkerasan tanpa cakar sebesar $27.70 \%$ dan $31,58 \%$.

Lendutan yang terjadi pada ketiga posisi beban (Tengah 1, Tengah 2, dan Tengah 3) menunjukkan bahwa lendutan yang terjadi pada sistem perkerasan tanpa cakar lebih besar dibandingkan dengan sistem CAM. Lendutan terkecil dihasilkan oleh sistem CAM dengan pola segitiga meskipun jumlah cakar yang terdapat pada sistem CAM berpola segiempat lebih banyak dibandingkan dengan sistem CAM berpola segitiga. Hal ini menunjukkan bahwa jumlah cakar pada suatu sistem perkerasan tidak berpengaruh banyak terhadap lendutan yang terjadi melainkan penyebaran cakar pada sistem perkerasan. Penyebaran cakar pada sistem CAM berpola segitiga lebih merata dibandingkan dengan sistem CAM berpola segiempat sehingga kekakuan strukturnya lebih baik. Selisih lendutan pada sistem CAM berpola segitiga mencapai 36,97 \% sedangkan sistem CAM berpola segiempat hanya $28,56 \%$.

\section{SIMPULAN}

Berdasarkan pembahasan di atas dapat ditarik kesimpulan sebagai berikut :

1. Posisi ekstrim yang menghasilkan lendutan terbesar adalah Tengah 1.

2. Jumlah cakar di dalam sistem CAM tidak mempengaruhi lendutan yang terjadi.

3. Sistem CAM berpola segitiga lebih baik dalam mereduksi lendutan yang terjadi dibandingkan dengan sistem CAM berpola segiempat.

4. Sistem CAM berpola segitiga mampu mereduksi lendutan mencapai $36,97 \%$ sedangkan pada sistem CAM berpola segiempat hanya $28,56 \%$.

\section{REFERENSI}

Firdiansyah, A. (2009). Evaluasi Dimensi Sistem Cakar Ayam Akibat Pengaruh Variasi Beban dan Kondisi Tanah. Tesis, Universitas Gajah Mada, Yogyakarta. 
Hardiyatmo, H. C (2014). Perancangan Sistem Cakar Ayam Modifikasi untuk Perkerasan Jalan Raya Edisi Kedua,Yogyakarta: Gadjah Mada University Press.

Mardiyanto, B. (2010). Studi Perilaku Pelat Beton Di Atas Tanah Dengan Metode Elemen Hingga (Sap 2000 V.11.0.0) Ditinjau Pada Variasi Modulus Reaksi Subgrade (Kv) dan Mutu Pelat Beton, Tugas Akhir, Universitas Sebelas Maret, Surakarta.

Rosyada, R. (2017). Perilaku Model Cakar Ayam pada Tanah Ekspansif berdasar Ketebalan Pelat dengan Menggunakan Metode Elemen Hingga (MEH), Tugas Akhir, Universitas Sebelas Maret, Surakarta.

Setiawan, B. (2015). Perilaku Sistem Cakar Ayam Modifikasi pada Tanah Ekspansif. Desertasi, Universitas Gajah Mada, Yogyakarta 